\title{
Analisis Kredit Macet Berdasarkan Umur Piutang Pada PT Mandala Multifinance Tbk
}

\author{
Eka Fitriani ${ }^{1}$, Oktariansyah ${ }^{2}$, Andri Eko Putra ${ }^{3}$ \\ ${ }^{1}$ Fakultas Ekonomi dan Bisnis Universitas PGRI Palembang, ekaf609@gmail.com \\ ${ }^{2}$ Fakultas Ekonomi dan Bisnis Universitas PGRI Palembang, rianbro82@univpgri-palembang.ac.id \\ ${ }^{3}$ Fakultas Ekonomi dan Bisnis Universitas PGRI Palembang andri ekoputra@yahoo.com
}

\begin{abstract}
This study aims to determine the percentage of losses experienced by PT. Mandala Multifinance Tbk from 2014-2018. In the midst of tight business competition the company is demanded to be able to gain market position, so the company needs to improve billing performance so that the amount of arrears does not increase every year. Receivables in general can be defined as claims arising from the sale of services or goods on credit. The research method used is descriptive qualitative method. The technique of collecting data is by studying the literature, namely studying literature, magazines, newspapers and other sources as well as publishing relevant to the issues discussed through literature study. From this data, it is analyzed using accounts receivable age and presentation of the final balance of accounts receivable using the arrears ratio. The results of this study indicate that losses incurred from uncollectible receivables of PT. Mandala Multifinance Tbk in 2014 amounted to $2.1 \%$, in 2015 there was an increase in bad debts by 2.3\%, in 2016 there was a rapid increase of $7.9 \%$, in 2017 there was an increase of $9.2 \%$, and in 2018 again experienced a quite rapid increase of $12.2 \%$.
\end{abstract}

Key words: accounts receivable, age of accounts receivable, ending balance using arrears ratio.

\begin{abstract}
ABSTRAK
Penelitian ini bertujuan untuk mengetahui besarnya persentase kerugian yang di alami oleh PT. Mandala Multi financeTbk dari tahun 2014-2018. Ditengah situasi persaingan bisnis yang ketat perusahaan dituntut untuk dapat meraih posisi pasar,sehingga perusahaan perlu melakukan peningkatan kinerja penagihan agar jumlah tunggakan tidak meningkat setiap tahunnya. Piutang secara umum dapat didefinisikan sebagai tagihan yang timbul akibat penjualan jasa atau barang secara kredit. Metode penelitian yang digunakan adalah metode deskriptif kualitatif. Tektik pengumpulan data yang dilakukan adalah dengan cara telaah kepustakaan yaitumempelajari literature-literature, majalah, surat kabar dan sumber-sumber lain serta penerbitan yang relevan dengan masalah yang dibahas melalui studi pustaka. Dari data ini dianalisis menggunakan umur piutang dan penyajian saldo akhir piutang menggunakan rasio tunggakan. Hasil penelitian ini menunjukkan bahwa kerugian yang ditimbulkan dari piutang tak tertagih PT. Mandala Multifinance Tbk Tahun 2014 sebesar sebesar2,1\%, ditahun 2015 mengalami peningkatan piutang tak tertagih sebesar2,3\%, ditahun 2016 mengalami peningkatan pesat sebesar 7,9\%, ditahun 2017 mengalami peningkatan sebesar 9,2\%, dan ditahun 2018 kembali mengalami peningkatan yang cukup pesat sebesar12,2\%.
\end{abstract}

Kata kunci: piutang, umur piutang, saldo akhir menggunakan rasio tunggakan.

\section{A. PENDAHULUAN}

Indonesia sebagai Negara yang sedang berkembang dituntut untuk ikut serta dalam melakukan pembangunan melalui pengembangan-pengembangan di bidang usaha. Beragamnya aktivitas usaha yang ada saat ini menuntut suatu perusahaan untuk siap bersaing dan meningkatkan strategi perusahaan sehingga dapat menarik 
minat konsumen. Oleh karena itu, untuk memaksimalkan kinerja perusahaan agar tetap bertahan dan semakin meningkat maka sektor swasta dan pemerintah harus mempersiapkan diri untuk bersaing baik dalam skala nasional maupun skala internasional.

Semakin berkembangnya suatu perusahaan, maka terkendalinya suatu aspekaspek yang ada pada perusahaan terutama dibagian piutang yang memiliki kemungkinan sulit untuk tetap berada pada kondisi yang tetap stabil karena jangkuan yang akan dikendalikan semakin luas dan komplek sehingga kemampuan manajemen dirasakan masih terbatas. Untuk menjaga keamanan kekayaan yang dimiliki oleh perusahaan maka manajemen dituntut untuk melakukan pengawasan serta pencegahan terhadap kesalahan dan penggelapan.

Berdasarkan tujuannya perusahaan dibedakan atas perusahaan berorientasi laba dan perusahaan berorientasi non laba. Perusahaan yang berorientasi laba merupakan perusahaan yang memiliki tujuan utama untuk mencapai keuntungan atau laba semaksimal mungkin.

Untuk mencapai tujuan suatu perusahaan, berbagai strategi yang jalankan oleh perusahaan seperti melakukan pembiayaan konsumen dengan memberikan pinjaman atau kredit kepada debitur untuk pembelian suatu barang atau pembayaran atas suatu jasa.Perusahaan mengharapkan laba dari suatu bunga yang didapat dari hasil pemberian kredit kepada konsumen. Pinjaman dalam bentuk piutang usaha yang akan ditagih pada saat jatuh tempo tersebut diberikan kepada konsumen yang bertujuan untuk memenuhi kebutuhan konsumen yang merupakan klaim dalam bentuk uang, barang atau jasa yang diberikan kepada pelanggan.

Peningkatan kinerja terus dilakukan oleh manajemen perusahaan guna menghindari terjadinya tunggakan-tunggakan yang berakibat pada kredit macet maka penghitungan piutang tak tertagih dapat diihat dari data umur piutag perusahaan. Salah satu ukuran keberhasilan suatu perusahaan yaitu dalam pencatatan piutang yang tertagih dapat dilakukan pemungutan secara maksimal sehingga terjadinya piurtang tak tertagih dapat diminimalis pada setiap tenggang umur piutang tersebut.

PT. Mandala MultifinanceTbk awalnya berdiri dengan nama PT. Vidya Cipta Leasing Corporation berdasarkan akta notaris Joenoes Enoeng Maogiman,S.H., No. 147 tanggal 13 Agustus 1983. Perusahaan mendapatkan izin untuk melakukan operasional kegiatan usaha sebagai perusahaan pembiayaan dari Menteri Keuangan dalam Surat Keputusan No. 323/KMK.017/1997 tanggal 21 juli 1997, yang merupakan perubahan keputusan pada tanggal 6 januari 1984 tentang pemberian izin kegiatan usaha Leasing kepada PT. Mandala Multifinance Tbk. Dengan mendapatkan izin tersebut maka perusahaan sebagai perusahaan yang bergerak dibidang pembiayaan tersebut maka dapat melakukan kegiatan dibidang sewa guna usaha, anjak piutang, usaha kartu kredit dan pembiayaan konsumen. Namun, kini perusahaan tersebut begerak dalam bidang pembiayaan konsumen.

\section{B. KAJIAN TEORI}

\section{Piutang}

Sasongko, dkk (2016:203) piutang adalah salah satu pos terbesar dalam asset lancar selain persediaan. Piutang terjadi pada umumnya karena perusahaan menjual barang atau jasa yang tidak secara tunai dalam upaya untuk meningkatkan penjualan perusahaan. Pengelolaan dan pengendalian piutang yang baik dan menandai sangat penting karena jika piutang yang diberikan tidak tertagih maka 
perusahaan akan mengalami kerugian. Maka pentingnya manajemen untuk menjaga kestabilan kinerja perusahaan dari segi pengendalian nasabah yang akan melakukan kredit dan penagihan secara berkala apabila konsumen tidak segera membayar.

STAK (2015:196)istilah piutang (receivable) meliputi semua klaim dalam bentuk uang terhadap pihak lainnya, termasuk individu, perusahaan, atau organisasi lainnya. Piutang biasanya memiliki bagian yang signifikan dari total asset lancar perusahaan.Piutang juga memiliki pengaruh penting terhadap laporan kuangan sehingga diperlukan perhitungan secara matang bagi manajemen pemberi kredit untuk mengontrol keadaan piutang perusahaan.

\section{Jenis-Jenis Piutang}

Secara umum, menurut STAK (2015:196) piutang dapat dikelompokkan sebagai berikut:

1. Piutang Usaha (Account Receivable)

Piutang usaha yaitu piutang yang memiliki periode kredit relative pendek seperti 30 hingga 60 hari dan umumnya digolongkan pada piutang usaha.Piutang usaha diklasifikasikan dineraca yaitu dalam asset lancer.

2. Wesel Tagiih (Notes Receivable)

Apabila suatu piutang untuk periode kredit lebih dari enam puluh hari, maka piutang tersebut pada umumnya digolongkan pada piutang wesel. Wesel tagih ialah jumlah yang terutang bagi pelanggan pada saat perusahaan sudah memberikan surat utang formal. Dalam wesel tagih diperkirakan piutang akan dapat tertagih dalam satu tahun, maka biasanya diklasifikasikan dalam neraca sebagai asset lancar.

3. Piutang lain-lain (Other Receivable)

Piutang lain-lain biasanya dilaporkan secara terpisah pada neraca. Apabila piutang ini diharapkan akan tertagih dalamsatu tahun, maka piutang tersebut diklasifikasikan sebagai asset tidak lancer serta dilaporkan dibawah judul investasi. Bagian-bagian dari piutang lain-lain meliputi piutang bunga, piutang pajak, piutang dari pejabat atau karyawan perusahaan.

\section{Faktor-Faktor Yang Mempengaruhi Jumlah Piutang}

Riyanto (2013:85), faktor-faktor yang mempengaruhi jumlah piutang adalah sebagai berikut:

1. Penjualan kredit.

2. Syarat pembayaran penjualan kredit.

3. Ketentuan dalam pembatasan kredit.

4. Kebijakan dalam pengumpulan piutang.

5. Cara membayar pelanggan.

\section{Piutang Usaha Tak Tertagih}

\section{Pengertian Piutang Usaha Tak Tertagih}

STAK (2015:198), piutang tak tertagih merupakan tagihan yang diharapkan dapat diterima namun kadang-kadang beberapa piutang nyatanya tidak dapat ditagih. Jumlah tersebut belum tentu sama dengan jumlah yang secara formal terdapat pada piutang, karena setiap piutang memiliki resiko tidak dapat ditagih. Perusahaan akan melakukan penyisihan piutang-piutang yang tidak dapat lagi 
ditagih dengan dengan mengurangkannya dari jumlah piutang tersebut. Piutang yang diperkirakan tidak dapat tertagih tersebut tercacat sebagai beban.

\section{Estimasi Piutang Tak Tertagih}

Dalam estimasi piutang tak tertagih dapat menggunakan persentase dari jumlah piutang usaha. Harry (2015:215) menyatakan "cara ini menekankan penilaian piutang usaha pada nilai bersihnya yang dapat direalisasi, yang nantinya akan dilaporkan dalam neraca atau dengan kata lain cara ini memfokuskan pada penetuan figure piutang usaha yang secara nyata dapat ditagih". Cara ini dapat dibagi menjadi dua metode, yaitu berdasarkan pada presentase dari jumlah saldo akhir piutang usaha danberdasarkan pada pengelompokan umur piutang.

1) Metode Umur Piutang

STAK (2015:199), umur piutang usaha ditentukan serta dilakukan untuk mengetahui jumlah dan lama nya piutang baik yang belum jatuh tempo maupun yang telah jatuh tempo. Metode umur piutang pertama kali, piutang usaha akan dikelompokkan berdasarkan masing-masing karateristik umurnya, yang artinya adanya pengelompokan piutang usaha kedalam kategori berdasarkan atas tanggal jatuh tempo piutang. Langkah berikutnya yaitu ialah menentukan persentase kredit macetuntuk masing-masing klasifikasi umur piutang sehingga akan diketahui jumlah taksiran kerugian piutang.

Membuat analisa umur piutang, dengan menggunakan tabel persentase sebagai berikut:

Tabel Persentase Umur Piutang Usaha

\begin{tabular}{|l|l|l|}
\hline $\begin{array}{l}\text { No } \\
\text { Piutang }\end{array}$ & $\begin{array}{l}\text { Kisaran Umur } \\
\text { Ping }\end{array}$ & $\begin{array}{l}\text { Persentase Tidak } \\
\text { Tertagih }\end{array}$ \\
\hline 1 & Belum Jatuh Tempo & $2 \%$ \\
\hline 2 & Telah Jatuh Tempo & \\
\hline & $\bullet \quad 1-30$ hari & $5 \%$ \\
& $\bullet \quad 31-60$ hari & $10 \%$ \\
& $\bullet \quad 61-90$ hari & $20 \%$ \\
& $\bullet \quad 181-180$ hari & $30 \%$ \\
& $\bullet \quad 365$ hari & $50 \%$ \\
& $>30 \%$ \\
\hline
\end{tabular}

Sumber : Herry (2015:221)

Lamanya umur piutang yang sudah jatuh tempo ini adalah lamanya hari mulai saat piutang tersebut jatuh tempo hingga laporan umur piutang (anging schedule) dibuat. Berdasarkan umur piutang, piutang yang sudah lama beredar (jatuh tempo) sangat kecil kemungkinan untuk bisa ditagih.

\section{2) Metode Saldo Akhir Piutang}

Dalam metode ini, persentase dari jumlah saldo akhir piutang usaha yang di estimasikan tidak dapat ditagih ditentukan. Jumah seluruh piutang disesuaikan dengan taksiran jumlah piutang yang tertagih agar menghasilkan saldo akhir yang nilainya akan menjadi hasil dari kerugian yang dialami oleh perusahaan tersebut. 
Dalam penyajian saldo akhir piutang, penulis menggunakan rasio tunggakan sebagai tujuan untuk mengetahui seberapa besar persentase piutang yang telah jatuh tempo.

Nurjannah (2012:53), rasio tunggakan bertujuan untuk mengetahui seberapa besar jumlah piutang yang telah jatuh tempo dan belum tertagih dari sejumlah penjualan kredit yang dilakukan.

Dan bila dituliskan dalam sebuah rumus, maka rasio tunggakan dapat dihitung dengan cara berikut ini :

\begin{tabular}{|l|l|}
\hline Rasio Tunggakan $=$ & piutang tak tertagih \\
& Total Piutang $100 \%$ \\
\hline
\end{tabular}

Dari rumus tersebut, kita bisa memahami bahwa cara penyajian kredit macetmenggunakan rasio tunggakan adalah seluruh piutang tak tertagih dibagi dengan total piutang lalu dikali $100 \%$.

\section{Piutang Ragu-Ragu}

\section{Pengertian Piutang Ragu-Ragu}

Sara (2016), timbulnya piutang bagi perusahaan akan membawa konsekuensi perlunya penanganan yang serius dimana diperlukan prosedur pencatatan piutang yang baik. Selain itu perencanaan pengawasan yang memadai dan efektif, kemungkinan besar piutang dapat terlunasi sesuai dengan tanggal jatuh temponya.

Sara (2016), menurut prinsip akuntansi, piutang tak tertagih akan dibebankan menjadi biaya operasi. Apabila biaya operasi semakin meningkat maka laba perusahaan akan menurun. Dalam laporan keuangan, piutang merupakan pos dari aktiva lancar yang dapat dijadikan sebagai investasi perusahaan. Jika jumlah piutang tak tertagih perusahaan cukup besar maka hal ini akan mengurangi jumlah piutang terealisasi sehingga membuat investasi perusahaan akan berkurang menyebabkan kerugian bagi perusahaan.

Pengertian piutang ragu-ragu menurut Sara (2016),"piutang ragu-ragu atau piutang tak tertagih merupakan kerugian pendapatan yang memerlukan ayat pencatatan yang tepat didalam perkiraan penurunan harta piutang serta penurunan yang berkaitan dalam laba dan ekuitas pemegang saham".

\section{Prosedur Jaminan}

\section{Pengertian Prosedur Jaminan}

Sitorus, dkk (2008), dalam pelaksanaan jaminan fiduasi sebagai keamanan dengan penyerahan jaminan kebendaan benda bergerak seperti STNK dari konsumen kepada perusahaan pembiayaan konsumen kendaraan bermotor sebagai kreditur. Jika konsumen tersebut tidak mampu melakukan kewajiban untuk membayar angsuran kendaraan tersebut maka kendaraan tersebut akan ditarik atau dilakukan eksekusi langsung oleh perusahaan pembiayaan konsumen. Setelah itu, kendaraan bermotor tadi akan dijual melalui pelanggan umum atau dijual langsung kepada konsumen yang berminat membeli kendaraan bermotor tersebut sebagai kendaraan bermotor bekas atan second hand.

\section{Laporan Keuangan}




\section{Pengertian Laporan Keuangan}

Pontoh (2013:26), laporan keuangan ialah tempat untuk pengkomunikasian informasi keuangan utama bagi pihak-pihak diluar perusahaan. Tujuan laporan keuangan tersebut ialah menyediakan informasi yang menyangkut posisi keuangan, kinerja perubahan posisi kuangan suatu perusahaan yang dapat bermanfaat bagi sejumlah besar pemakai dalam pengambilan keputusan ekonomi.

\section{Penelitian Terdahulu Yang Relevan}

Penelitian-penelitian terdahulu dapat digunakan sebagai pendukung dan juga dapat membantu dalam menelaah masalah yang dibahas dalam penelitian.Selain itu memberikan pemahaman terhadap posisi peneliti.

Untuk membedakan penelitian terdahulu yang telah dilakukan.Berikut ini beberapa hasil penelitian terdahulu sebagai bentuk dari bahan acuan dalam penelitian.

Puspita (2019) berjudul Analisis Sistem Pengendalian Intern Piutang Dalam Meminimalisir Piutang Tak Tertagih Pada PT. Cakrawala Multi Finance Palembang, Hasil penelitian tersebut menunjukkan bahwa kredit yang bermasalah pada tahun 2015, 2016 serta 2017 sebesar 50, 38\%, 53,83\%, 56,83\% hal tersebut menandakan perusahaan masih memiliki kekurangan apabila dinilai dari keempat unsur pengendalian intern.

Costa' (2015), berjudul Analisis Kredit macetTak Tertagih Pada PT. Metta Karuna Jaya Makassar. Hasil penelitian menunjukkan perusahaan menggunakan metode penghapusan langsung dalam hal penentuan beban kerugian piutangnya.

Demak, dkk (2018) berjudul Analisis Piutang Tak Tertagih Berdasarkan Umur Piutang Pada PT. Air Manado, Hasil penelitian ini menunjukkan bahwa pencacatan akun tidak tertagih pada PT. Air Manado bagus karena sesuai dengan kententuan dan perjajian dengan investor juga telah sesuai dengan teori metode umur piutang.

\section{METODE PENELITIAN}

1. Populasi dan Sampel

Mulyiddin (2018:70), populasi merupakan kelompok individu yang memiliki karakteristik tertentu serta dapat dibedakan dari kelompok lain yang juga memiliki karakterik tertentu. Populasi dalam penelitian ini adalah data piutang dan data umur piutang pada PT. Mandala Multifinance Tbk

Mulyiddin (2018:70), sampel merupakan bagian dari jumlah populasi yang kemudian diteliti serta dianggap telah mewakili atau mencerminkan populasi tersebut. Sampel dalam penelitian ini adalah data piutang dan data umur piutang pada PT. Mandala Multifinance Tbk tahun 2014-2018.

\section{Sumber Data}

Data yang digunakan dalam penelitian ini adalah data sekunder. Dalam penelitian ini yaitu data di peroleh dari Galeri Investasi Bursa Efek Indonesia berupa data laporan keuangan pada perusahaan PT. Mandala Multifinance Tbk tahun 2014-2018.

\section{Teknik Pengumpulan Data}

Sugiyono (2013: 224), teknik pengumpulan data adalah langkah yang paling strategis dalam penelitian, karena tujuan utama dari penelitian adalah mendapatkan sebuah data. 
Teknik pengumpulan data dalam penelitian ini menggunakan cara telaah kepustakaan.

\section{Teknik Analisis Data}

Sugiyono (2015: 13-14), teknik analisis data dalam penelitian ini dibagi menjadi dua yaitu:

1. Analisis Kualitatif

Analisis kualitatif yaitu suatu metode analisis dengan menggunakan data yang berbentuk gambar, kalimat, skema dan kata.

\section{Analisis kuantitatif}

Analisis kuantitatif yaitu suatu metode penelitian dengan menggunakan data yang berbentuk angka atau kualitatif yang di angkakan.

Hikmawati (2018:88), penelitian deskriptif ialah penelitian yang mengarah untuk mengumpulkan informasi mengenai status suatu gejala yang ada dan berkaitan, yaitu kondisi gejala menurut apa adanya pada saat penelitian dilakukan tanpa bermaksut membuat kesimpulan yang berguna dan berlaku untuk umum atau generalisasi.

Teknik analisis data dalam penelitian ini adalah deskriptif kualitatif. Teknik dalam suatu penelitian merupakan suatu bagian yang sangat penting. Peneliti menganalisis dan membandingkan selisih hasil perhitungan piutang tak tertagih menggunakan penghitungan saldo akhir dan umur pada perusahaan PT. Mandala Multifinance Tbk.

\section{HASIL PENELITIAN DAN PEMBAHASAN}

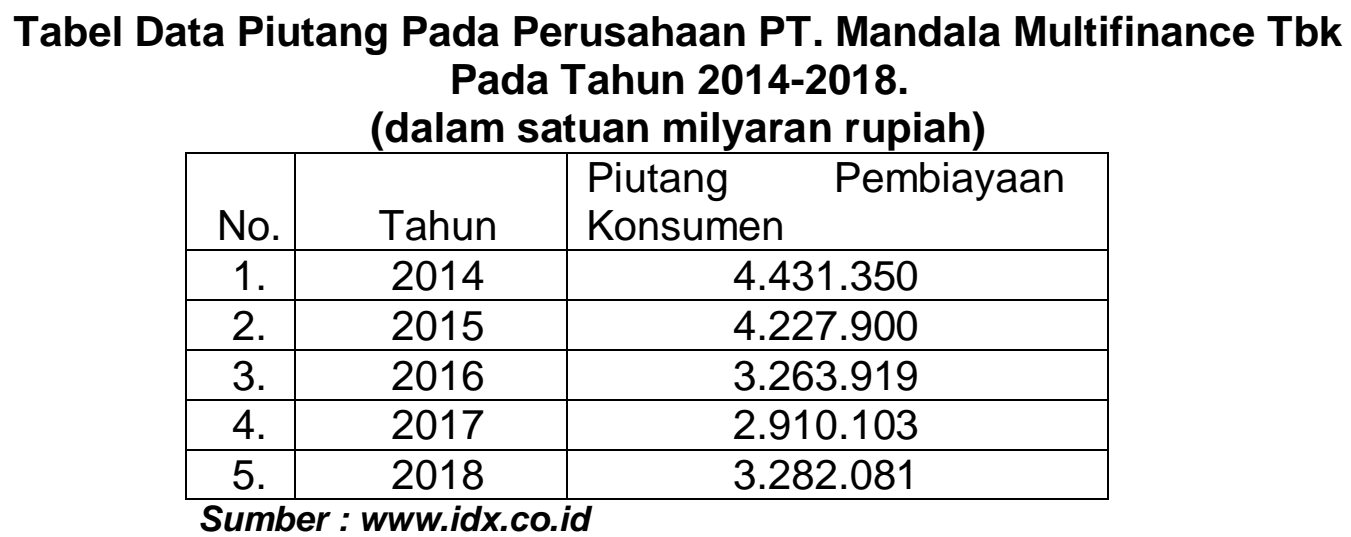

Dapat dilihat data yang diperoleh dari PT. Mandala Multifinance Tbk melalui Bursa Efek Indonesia bahwa ditahun 2014 mengalami macet sebesar Rp. 4.431.350.000., tahun 2015 perusahaan mengalami kredit macet sebesar Rp. 4.227.900.000., tahun 2016 perusahaan mengalami kredit macet sebesar Rp. 3.263.919.000, tahun 2017 perusahaan mengalami kredit macet sebesar Rp. 2.910.103.000 dan ditahun 2018 perusahaan mengalami kredit macet sebesar Rp. 3.282.081.000, maka setiap tahunnya piutang PT. Mandala Multifinance Tbk mengalami peningkatan dan penurunan yang tidak dapat perkirakan jumlahnya sehingga menjadikan perusahaan tersebut untuk lebih mengoptimalkan kinerja manajemen kredit dalam pemilihan nasabah atau konsumen yang sesuai kriteria 
perusahaan dan memaksimalkan penagihan kepada pihak yang bersangkutan serta penghitungan secara tepat untuk menilai kondisi piutang yang dapat digunakan sebagai acuan dalam meningkatkan kinerja dimasa mendatang.

\section{a. Penghitungan Umur Piutang}

Membuat analisa umur piutang, dengan menggunakan tabel persentase sebagai berikut:

Tabel Daftar Persentase Umur Piutang Usaha

\begin{tabular}{|l|l|c|}
\hline No & Kisaran Umur Piutang & Persentase Tidak Tertagih \\
\hline 1 & Belum Jatuh Tempo & $2 \%$ \\
\hline 2 & Telah Jatuh Tempo & \\
\hline \multirow{1}{*}{} & $\bullet \quad 1-30$ hari & $5 \%$ \\
& $\bullet \quad 31-60$ hari & $10 \%$ \\
& $\bullet \quad 61-90$ hari & $20 \%$ \\
& $\bullet 91-180$ hari & $30 \%$ \\
& $\bullet \quad 181-365$ hari & $50 \%$ \\
& $\bullet \quad 365$ hari & $80 \%$ \\
\hline
\end{tabular}

Sumber :Herry (2015:221)

Lamanya umur piutang yang sudah jatuh tempo ini adalah lamanya hari mulai saat piutang tersebut jatuh tempo hingga laporan umur piutang (anging schedule) dibuat. Berdasarkan umur piutang, piutang yang sudah lama beredar (jatuh tempo) sangat kecil kemungkinan untuk bisa ditagih.

STAK (2015:199), pengelompokan piutang usaha kedalam kategori berdasarkan atas tanggal jatuh tempo piutang, maka hasil penghitungan umur piutang adalah sebagai berikut:

Tabel Daftar Umur Piutang Tahun 2014 (dalam satuan jutaan rupiah)

\begin{tabular}{|l|l|l|l|l|l|}
\hline \multirow{2}{*}{ No. } & \multicolumn{3}{|c|}{ Umur } & \multirow{2}{*}{ Jumlah } \\
\cline { 2 - 5 } & $1-30$ (hari) & $31-60$ (hari) & $61-90$ (hari) & $>91$ (hari) & \\
\hline 1. & 36.476 & 18.587 & 10.833 & 26.377 & 92.273 \\
\hline
\end{tabular}

Sumber: Hasil pengolahan data tahun 2020

Berdasarkan tabel analisis umur piutang dapat dilihat bahwa besarnya piutang menunggak 1-30 hari sebesar Rp.36.476.000, 31-60 hari sebesar Rp.18.587.000, 61-90 hari sebesar Rp.10.833.000 dan >91 hari sebesar Rp.26.377.000. jumlah piutang tak tertagih tahun 2014 sebesar Rp.92.273.000, terlihat bahwa jumlah piutang tak tertagih masih sangat besar.

Tabel Saldo Penyisihan Piutang Tak Tertagih Tahun 2014 (dalam satuan jutaan rupiah)

\begin{tabular}{|l|l|l|l}
\hline \multicolumn{1}{|l|}{ Ikhtisar } & $\begin{array}{l}\text { Persentase estimasi } \\
\text { tak tertagih }\end{array}$ & $\begin{array}{l}\text { Saldo yang diperlukan dalam } \\
\text { penyisihan }\end{array}$ \\
\hline
\end{tabular}




\begin{tabular}{|l|l|l|l|}
\hline & & & \\
\hline $1-30$ & 36.476 & $5 \%$ & 1.822 \\
\hline $31-60$ & 18.587 & $10 \%$ & 1.859 \\
\hline $61-90$ & 10.833 & $20 \%$ & 2.167 \\
\hline$>91$ & 26.377 & $30 \%$ & 7.901 \\
\hline Sado penyisiha piutang tak tertagih =13.749 \\
Sumber: Hasil pengolahan data tahun 2020
\end{tabular}

Berdasarkan tabel saldo penyisihan piutang tak tertagih ditahun 2014 sebesar Rp.13.749.000.

Tabel Daftar Umur Piutang Tahun 2015 (dalam satuan jutaan rupiah)

\begin{tabular}{|l|l|l|l|l|l|}
\hline \multirow{2}{*}{ No. } & \multicolumn{3}{|l|}{ Umur } & \multirow{2}{*}{ Jumlah } \\
\cline { 2 - 5 } & $1-30$ (hari) & $31-60$ (hari) & $61-90$ (hari) & $>91$ (hari) & \\
\hline 1. & 43.926 & 15.361 & 11.243 & 26.170 & 96.736 \\
\hline
\end{tabular}

Sumber: Hasil pengolahan data tahun 2020

Berdasarkan tabel analisis umur piutang dapat dilihat bahwa besarnya piutang menunggak 1-30 hari sebesar Rp.43.926.000, 31-60 hari sebesar Rp.15.361.000, 61-90 hari sebesar Rp.11.243.000, >91 hari sebesar Rp.26.170.000. Jumlah piutang tak tertagih tahun 2015 sebesar Rp.96.736.000, terlihat bahwa jumlah piutang tak tertagih meningkat dari tahun sebelumnya

Tabel Saldo Penyisihan Piutang Tak Tertagih Tahun 2015 (dalam satuan jutaan rupiah)

\begin{tabular}{|l|l|l|l|}
\hline Ikhtisar & Jumlah & $\begin{array}{l}\text { Persentase estimasi tak } \\
\text { tertagih }\end{array}$ & $\begin{array}{l}\text { Saldo yang diperlukan dalam } \\
\text { penyisihan }\end{array}$ \\
\hline Umur & & $5 \%$ & 2.198 \\
\hline $1-30$ & 43.926 & $5 \%$ & 1.536 \\
\hline $31-60$ & 15.361 & $10 \%$ & 2.249 \\
\hline $61-90$ & 11.243 & $20 \%$ & 7.851 \\
\hline$>91$ & 26.170 & $30 \%$ & \\
\hline Sado penyisiha piutang tak tertagih $=13.834$ \\
\hline
\end{tabular}

Sumber: Hasil pengolahan data tahun 2020

Berdasarkan tabel saldo penyisihan piutang tak tertagih ditahun 2015 sebesar Rp.13.834.000, jumlah ini menigkat dari tahun sebelumnya.

Tabel Daftar Umur Piutang Tahun 2016 (dalam satuan jutaan rupiah)

\begin{tabular}{|l|l|l|l|l|l|}
\hline \multirow{2}{*}{ No. } & \multicolumn{3}{|l|}{ Umur } & \multirow{2}{*}{ Jumlah } \\
\cline { 2 - 5 } & $1-30$ hari) & $31-60$ (hari) & $61-90$ (hari) & $>91$ (hari) & \\
\hline 1. & 173.643 & 43.860 & 19.566 & 23.835 & 260.904 \\
\hline
\end{tabular}

Sumber: Hasil pengolahan data tahun 2020 
Berdasarkan tabel analisis umur piutang dapat dilihat bahwa besarnya piutang menunggak 1-30 hari sebesar Rp.173.643.000, 31-60 hari sebesar Rp.43.860.000, 61-90 hari sebesar Rp.19.566.000, >91 hari sebesar Rp.23.835.000. Jumlah piutang tak tertagih tahun 2016 sebesar Rp.260.904.000, terlihat bahwa jumlah tersebut mengalamni peningkatan yang signifikan dari tahun sebelumnya.

Tabel Saldo Penyisihan Piutang Tak Tertagih Tahun 2016 (dalam satuan jutaan rupiah)

\begin{tabular}{|c|c|c|c|c|}
\hline \multicolumn{5}{|c|}{ Ikhtisar } \\
\hline Umur & Jumlah & $\begin{array}{l}\text { Persentase } \\
\text { tak tertagih }\end{array}$ & estimasi & $\begin{array}{l}\text { Saldo yang diperlukan dalam } \\
\text { penyisihan }\end{array}$ \\
\hline $1-30$ & 173.643 & $5 \%$ & & 8.628 \\
\hline $31-60$ & 43.860 & $10 \%$ & & 4.386 \\
\hline $61-90$ & 19.566 & $20 \%$ & & 3.913 \\
\hline$>91$ & 23.835 & $30 \%$ & & 7.151 \\
\hline
\end{tabular}

Sumber: Hasil pengolahan data tahun 2020

Berdasarkan tabel saldo penyisihan piutang tak tertagih ditahun 2016 sebesar Rp.24.132.000, jumlah ini meningkat dari tahun sebelumnya.

Tabel Daftar Umur Piutang Tahun 2017 (dalam satuan jutaan rupiah)

\begin{tabular}{|l|l|l|l|l|l|}
\hline \multirow{2}{*}{ No. } & \multicolumn{3}{|l|}{ Umur } & \multirow{2}{*}{ Jumlah } \\
\cline { 2 - 5 } & $\begin{array}{l}1-30 \\
\text { (hari) }\end{array}$ & $\begin{array}{l}31-60 \\
\text { (hari) }\end{array}$ & $\begin{array}{l}61-90 \\
\text { (hari) }\end{array}$ & $\begin{array}{l}> \\
\text { (hari) }\end{array}$ & \\
\hline 1. & 168.121 & 43.437 & 21.608 & 35.234 & 268.400 \\
\hline
\end{tabular}

Sumber: Hasil pengolahan data tahun 2020

Berdasarkan tabel, analisis umur piutang dapat dilihat bahwa besarnya piutang menunggak 1-30 hari sebesar Rp.168.121.000, 31-60 hari sebesar Rp.43.437.000, 61-90 hari sebesar Rp.21.608.000, >91 hari sebesar Rp.35.234.000. Jumlah piutang tak tertagih tahun 2017 sebesar Rp.268.400.000, terlihat bahwa jumlah tersebut mengalamni peningkatan dari tahun sebelumnya namun tidak terlalu signifikan.

Tabel Saldo Penyisihan Piutang Tak Tertagih Tahun 2017 (dalam satuan jutaan rupiah)

\begin{tabular}{|c|c|c|c|}
\hline \multicolumn{4}{|c|}{ Ikhtisar } \\
\hline Umur & Jumlah & $\begin{array}{l}\text { Persentase estimasi } \\
\text { tak tertagih }\end{array}$ & $\begin{array}{l}\text { Saldo yang diperlukan dalam } \\
\text { penyisihan }\end{array}$ \\
\hline $1-30$ & $\begin{array}{l}168.12 \\
1\end{array}$ & $5 \%$ & 8.406 \\
\hline $31-60$ & 43.437 & $10 \%$ & 4.344 \\
\hline $61-90$ & 19.566 & $20 \%$ & 4.327 \\
\hline$>91$ & 23.835 & $30 \%$ & 10.570 \\
\hline
\end{tabular}


Sado penyisiha piutang tak tertagih $=27.647$

Sumber: Hasil pengolahan data tahun 2020

Berdasarkan tabel saldo penyisihan piutang tak tertagih ditahun 2017 sebesar Rp.27.647.000, jumlah ini meningkat dari tahun sebelumnya.

Tabel Daftar Umur Piutang Tahun 2018

(dalam satuan jutaan rupiah)

\begin{tabular}{|l|l|l|l|l|l|}
\hline \multirow{2}{*}{ No. } & \multicolumn{4}{|l|}{ Umur } & \multirow{2}{*}{ Jumlah } \\
\cline { 2 - 5 } & $\begin{array}{l}1-30 \\
\text { (hari) }\end{array}$ & $\begin{array}{l}31-60 \\
\text { (hari) }\end{array}$ & $\begin{array}{l}61-90 \\
\text { (hari) }\end{array}$ & $\begin{array}{l}> \\
\text { (hari) }\end{array}$ & \\
\hline 1. & 213.579 & 59.795 & 70.922 & 57.139 & 401.435 \\
\hline
\end{tabular}

Sumber: Hasil pengolahan data tahun 2020

Berdasarkan tabel analisis umur piutang dapat dilihat bahwa besarnya piutang menunggak 1-30 hari sebesar Rp.213.579.000, 31-60 hari sebesar Rp.59.795.000, 61-90 hari sebesar Rp.70.922.000, >91 hari sebesar Rp.57.139.000. Jumlah piutang tak tertagih tahun 2018 sebesar Rp.401.435.000, terlihat bahwa jumlah tersebut mengalamni peningkatan yang signifikan dari tahun-tahun sebelumnya.

Tabel Saldo Penyisihan Piutang Tak Tertagih Tahun 2018 (dalam satuan jutaan rupiah)

\begin{tabular}{|c|c|c|c|}
\hline \multicolumn{4}{|c|}{ Ikhtisar } \\
\hline Umur & Jumlah & $\begin{array}{l}\text { Persentase estimasi } \\
\text { tak tertagih }\end{array}$ & $\begin{array}{l}\text { Saldo yang diperlukan dalam } \\
\text { penyisihan }\end{array}$ \\
\hline $1-30$ & $\begin{array}{l}213.57 \\
9\end{array}$ & $5 \%$ & 10.679 \\
\hline $31-60$ & 59.795 & $10 \%$ & 5.979 \\
\hline $61-90$ & 70.922 & $20 \%$ & 14.184 \\
\hline$>91$ & 57.139 & $30 \%$ & 17.142 \\
\hline
\end{tabular}

Sumber: Hasil pengolahan data tahun 2020

Berdasarkan tabel saldo penyisihan piutang tak tertagih ditahun 2018 sebesar Rp. 47.984.000, jumlah ini meningkat dari tahun sebelumnya

\section{b. Penyajian Saldo Akhir Piutang Menggunakan Rasio Tunggakan}

Berdasarkan hasil penelitian yang penulis lakukan pada PT. Mandala Multifinance Tbk, diketahui bahwa sistem administrasi dan pengawasan sudah dilakukan dengan cukup baik, namun masih saja terjadi piutang tak tertagih dalam sistem pemberian kredit pada PT. Mandala Multifinance Tbk.

Untuk mengetahui persentase kredit macet pada PT. Mandala Multifinance Tbk, maka dilakukan perhitungan rasio tunggakan.

Nurjannah (2012:53), rasio tunggakan bertujuan untuk mengetahui seberapa besar jumlah piutang yang telah jatuh tempo dan belum tertagih dari sejumlah penjualan kredit yang dilakukan. 
Dan bila dituliskan dalam sebuah rumus, maka rasio tunggakan dapat dihitung dengan cara berikut ini :

1. Tahun 2014

$$
\text { Rasio Tunggakan }=\frac{\text { Piutang tak tertagih }}{\text { Total piutang }} \times 100 \%
$$$$
\text { Rasio Tunggakan }(\text { Persentase })=\frac{92.273}{4.431 .350} \times 100 \%=2,1 \%
$$

Ditahun 2014 PT. Mandala Multifinance Tbk mengalami kredit macet sebesar $2,1 \%$, hal tersebut terjadi karena jumlah piutang tak tertagih ditahun tersebut sebesar Rp.92.273.000 dengan jumlah piutang sebesar Rp.4.431.350.000.

\section{Tahun 2015}

Rasio Tunggakan $($ Persentase $)=\frac{96.736}{4.227 .900} \times 100 \%=2,3 \%$

Ditahun 2015, PT. Mandala Multifinance Tbk mengalami kredit macet sebesar 2,3\%, hal tersebut terjadi karena jumlah piutang tak tertagih ditahun tersebut sebesar Rp96.736.000 dengan jumlah piutang sebesar Rp.4.227.900.000 , dimana jumlah piutang menurun dari tahun sebelumnya serta piutang tak tertagih meningkat dari tahun sebelumnya.

\section{Tahun 2016}

Rasio Tunggakan $($ Persentase $)=\frac{260.904}{3.263 .919} \times 100 \%=7,9 \%$

Ditahun 2016, PT. Mandala Multifinance Tbk mengalami kredit macet sebesar $7,9 \%$, hal tersebut terjadi karena jumlah piutang tak tertagih ditahun tersebut sebesar Rp.260.904.000 dengan jumlah piutang sebesar Rp.3.263.919.000, dimana jumlah piutang menurun dari tahun sebelumnya serta jumlah piutang tak tergih semakin meningkat dari tahun sebelumnya.

\section{Tahun 2017}

$$
\text { Rasio Tunggakan (Persentase) }=\frac{268.400}{2.910 .103} \times 100 \%=9,2 \%
$$

Ditahun 2017, PT. Mandala Multifinance Tbk mengalami kredit macet sebesar $9,2 \%$, hal tersebut terjadi karena jumlah piutang tak tertagih ditahun tersebut sebesar Rp.268.400.000 dengan jumlah piutang sebesar Rp.2.910.103.000, dimana jumlah piutang menurun dari tahun sebelumnya serta jumlah piutang tak tergih mengalami peningkatan dari tahun sebelumnya.

\section{Tahun 2018}

$$
\text { Rasio Tunggakan (Persentase) }=\frac{401.435}{3.282 .081} \times 100 \%=12,2 \%
$$

Ditahun 2018, PT. Mandala Multifinance Tbk mengalami kredit macet sebesar $12,2 \%$, hal tersebut terjadi karena jumlah piutang tak tertagih ditahun tersebut sebesar Rp.401.435.000 dengan jumlah piutang sebesar Rp.3.282.081.000, dimana jumlah piutang mengalami peningkatan dari tahun 
sebelumnya serta jumlah piutang tak tergih mengalami peningkatan yang cukup tinggi dari tahun sebelumnya.

Berikut ini disajikan pada tabel 10 mengenai jumlah piutang tak tertagih dan piutang tertagih pada tahun 2014-2018 yang ditunjukkan pada tabel berikut ini:

\section{Tabel Daftar Jumlah Piutang, Piutang Tertagih Dan Piutang Tak Tertagih Pada PT. Mandala Multifinance Tbk}

Tahun 2014-2018

\begin{tabular}{|c|c|c|c|c|c|}
\hline \multirow[b]{2}{*}{ No. } & \multirow[b]{2}{*}{ Tahun } & \multicolumn{3}{|l|}{ Jumlah } & \multirow[b]{2}{*}{ Persentase } \\
\hline & & piutang & $\begin{array}{l}\text { Piutang } \\
\text { Tertagih }\end{array}$ & $\begin{array}{l}\text { Piutang Tak } \\
\text { Tertagih }\end{array}$ & \\
\hline 1. & 2014 & 4.431 .350 & 4.339 .077 & 92.273 & $2,1 \%$ \\
\hline 2. & 2015 & 4.227 .900 & 4.131 .164 & 96.736 & $2,3 \%$ \\
\hline 3. & 2016 & 3.263 .919 & 3.003 .015 & 260.904 & $7,9 \%$ \\
\hline 4. & 2017 & 2.910 .103 & 2.641 .703 & 268.400 & $9,2 \%$ \\
\hline 5. & 2018 & 3.282 .081 & 2.880 .646 & 401.435 & $12,2 \%$ \\
\hline
\end{tabular}

Sumber : Data Olahan 2020

Berdasarkan tabel diatas dapat diketahui bahawa rasio tunggakan atau piutang tak tertagih pada PT. Mandala Multifinance Tbk pada tahun 2014 menunjukkan sebesar 2,1\%, tahun 2015 sebesar 2,3\%, tahun 2016 sebesar 7,9\%, tahun 2017 sebesar 9,2 dan tahun 2018 sebesar 12,2\%. Tunggakan tertinggi terjadi pada tahun 2018 dan dapat merugikan perusahaan karena dana yang harusnya kembali berputar menjadi kas tetap tertanam dalam piutang. Semakin kecil rasio tunggakan maka berarti semakin baik bagi perusahaan dalam mengelola piutangnya dan sebaliknya semakin besar rasio tunggakan maka berarti semakin buruh bagi perusahaan dalam mengelola piutangnya.

Apabila dibandingkan dengan penelitian yang dilakukan oleh Susanti pada PT. Cakrawala Multi Finance Palembang ditahun 2019, tentunya persentase kredit macet yang dialami oleh PT. Cakrawala Multi Finance Palembang 2015 sebesar 50, 38\%,, 2016 sebesar 53,83\%, serta 2017 sebesar 56,83\% berbeda dengan persentase yang di alami oleh PT. Mandala Multifinance Tbk yaitu ditahun 2014 menunjukkan sebesar 2,1\%, tahun 2015 sebesar 2,3\%, tahun 2016 sebesar 7,9\%, tahun 2017 sebesar 9,2 dan tahun 2018 sebesar 12,2\%.

Walaupun PT. Mandala Multifinance tingkat kredit macetnya lebih rendah, hal ini tentunya harus menjadikan motivasi dan memerlukan perhatian khusus untuk masing-masing perusahaan agar terus meningkat manajemen penagihan sehingga kredit macet dapat terus mengalami penurunan setiap tahunnya.

\section{E. KESIMPULAN DAN SARAN}

1. Kesimpulan

Dari penelitian yang telah dilakukan maka dapat diambil suatu kesimpulan yaitu:

a. Berdasarkan data umur piutang lalu kemudian dihitung menggunakan rasio tunggakan untuk mengetahui saldo akhir perusahaan maka perusahaan mengalami kerugian akibat piutang tak tak tertagih kepada pelanggan ditahun 2014 sebesar $2,1 \%$, ditahun 2015 mengalami peningkatan piutang tak tertagih 
sebesar 2,3\%, ditahun 2016 mengalami peningkatan pesat sebesar 7,9\%, ditahun 2017 mengalami peningkatan sebesar 9,2\%, dan ditahun 2018 kembali mengalami peningkatan yang cukup pesat sebesar $12,2 \%$.

b. Berdasarkan data umur piutang dapat dilihat bahwa sebagian besar pelanggan yang mengalami tunggakan umur piutang ialah pada $>90$ hari yang dikategorikan tidak aman dibandingkan dengan kategori umur piutang dibawahnya.

\section{Saran}

Saran yang dapat diberikan kepada PT. Mandala Multifinance Tbk adalah:

a. Agar pihak perusahaan dapat mempertahankan kinerja yang selama ini sudah baik dalam hal pengelolaan piutang serta dilihat dari persentase piutang tak tertagih yang semakin meningkat hal ini dapat dilihat dari angka yang ditunjukkan pada penghitungan metode umur piutang dan penghitungan metode saldo akhir menggunakan rasio tunggakan, maka perusahaan harus lebih selektif dalam memilih pelanggan dengan kriteria yang telah ditetapkan perusahaan dan bukan hanya pelanggan yang diperhatikan namun juga manajemen penagihan yang tepat dapat memberikan pengaruh terhadap penurunan jumlah persentase piutang tak tertagih.

b. Agar bagian penagihan tetap konsisten meningkatkan kinerja dalam melaksanakan prosedur penagihan piutang dan prosedur evaluasi penagihan piutang, sehingga umur piutang di PT. Mandala Multifinance semuanya masuk dalam kategori aman.

\section{DAFTAR PUSTAKA}

Bursa Efek Indonesia, Laporan Keuangan Tahunan 2014, 2015, 2016, 2017, 2018.www.idx.co.id. Diakses pada hari senin, 24 februari 2020.

Costa', Imanuella Fensi da. 2015. Analisis kredit macettak tertagih pada PT. Metta Karuna Jaya Makassar. Jurnal EMBA. Vol III. No.1. 2015

Demak, dkk. 2018. Analisis piutang tak tertagih berdasarkan umur piutang pada PT. Air Manado. Jurnal Riset Akuntansi. Vol.XIII. No.4. 2018

Nurjannah. 2012. Analisis Tingkat Perputaran Piutang Pada PT. Adira Finance Makassar, skripsi. Jurusan Akuntansi Fakultas Ekonomi dan Bisnis Universitas Hasanuddin

Mulyiddin, dkk.2018. Metodologi Penelitian Ekonomi Dan Social.Salemba Empat: Jakarta

Pontoh, Winston. 2013.Akuntansi Konsep Dan Aplikasi. Halaman Moeka: Jakarta

Puspita, Santi. 2019. Analisis Sistem Pengendalian Intern Piutang Dalam Meminimalisir Piutang Tak Tertagihpada PT. Cakrawala Multi Finance Palembanng.Vol.15. No.1. 2019 
Sara. 2016. Pengelolaan Piutang Ragu-Ragu Pada PT.PLN (Persero) Rayon Medan Selatan. Skripsi. Fakultas Ekonomi Dan Bisnis Universitas Sumatera Utara Medan

Sasongko, dkk. 2016. Akuntansi suatu pengantar berbasis PSAK. Salemba Empat: Jakarta

Sitorus, dkk. 2008. Jaminan Fiduasi Dalam Perjanjian Pembiayaan Konsumen Kendaraan Bermotor Ditinjau Dari Aspek Hukum Perdata Pada PT. Mandala Multifinance Tbk Di Jakarta. Tesis. Magister Hukum Universitar Gadjah Mada

Sugiyono. 2013. Metode Penelitian Pendidikan Pendekatan Kuantitatif Kualitatif dan $R \& D$. Bandung: Alfabeta.

STAK. 2015. Pengantar Akuntansi Berbasis SAK ETAP. Cetakan Pertama. Ikatan Akuntansi Indonesia Wilayah Sumatera Selatan: Palembang. 